\title{
Stir design to improve uniform distribution of composite materials in stir casting process
}

\author{
Sahil Kumar Prajapati ${ }^{1 *}$ and Neeraj Kumar ${ }^{2}$ \\ M. Tech Student, Manufacturing and Industrial Engineering, Suresh Gyan Vihar University, Jaipur, India \\ Professor and HOD, Department of Mechanical Engineering, Suresh Gyan Vihar University, Jaipur, India
}

\section{(C2018 ACCENTS}

\begin{abstract}
In our research work the main objective is to improve uniform distribution by stirring reinforcements in the base metal (aluminium). This project deals with the stir design to improve uniform distribution of composite materials in stir casting process. To study this project the stir design is carried out in CREO 2.0. We have designed stir of graphite of helical shape. To get better results we designed helical shape stir. And we have also given thermal analysis of stir materials by ANSYS. By mixing reinforcement (5\%) and base material with helical stir, it results silicon content in sample is $2.422 \%$ and aluminium is 95.18 .
\end{abstract}

\section{Keywords}

Matrix metals, Reinforcement, Uniform distribution, Stirrer, High alumina bricks.

\section{Introduction}

Stir casting is one of the prominent and economical technique for development and processing of metal matrix composites (MMC's) materials. Composite material properties has increased strength, high elastic modulus, and higher service temperature, improved wear resistance, decreased part weight, lower thermal shocks, higher electrical and thermal conductivity, and lower coefficient of thermal expansion compound compared to conventional metal and alloys. The excellent mechanical properties of these materials and the relatively low producing cost make them very attractive for a variety of application in automotive and aerospace industries.

The main difficulty in the stir casting process is distribution of reinforcement in base material.

Due to this problem the ultimate tensile strength, stiffness, hardness and yield strength, of the composite becomes poor because the ceramic materials have different density, melting point and boiling point. However, other light materials like Aluminum, copper, magnesium etc. have less density, melting point and boiling point, so ceramic particle mixing is very difficult in light materials.
This research is based on vast literature survey and finds gaps in exist literature as follows:

1. In all previous research uniform distribution of materials in composite material is not focused properly, they just focus on the production and optimization of the composites.

2. The design of impeller is not proper which can perform uniform distribution.

3. In some research papers they described that impeller is designed by the help of impeller blades which are welded on the stir rod. Due to increase in heat generation welded zone may break.

4. Due to non-uniform distribution of composite material may result in same mechanical or thermal properties at some points on composites or may less.

Our objective of this work is to improve the distribution of reinforcement with base material which can improve the chemical and mechanical properties.

This research deals with an introduction to composite materials, types of composite, stir casting method and a brief introduction to ANSYS required for designing the stir to obtain a uniform distribution of composite material during stir casting process. 


\section{Literature review}

In 2015, Saravanan et al. [1] described the speed of stir rotation, preheating of reinforcement, stirring time, and stirring temperature. But researchers didn't describe their design of stir.

In 2015, Kumar et al. [2] explained their work on wear analysis of aluminium only based composite materials made by stir casting process but they didn't explained their casting method and design of stir.

In 2015, Almadhoni and Khan [3] explained their work with 3 types of stirs. They used experimental design image from other source and they are also weak to describe their design of stir by chemical composition test reports. They showed 3 types of stir but they didn't show that which of their design was successful.

In 2015, Sadi et al. [4] explained their optimization work on composite material made by aluminium and silicon carbide. But they didn't describe their stir design.

In 2014, Mansoor and Shahid [5] researchers introduced induction coil mechanism for melting of aluminium. According to researchers they are also use this induction coil mechanism for stirring of aluminium with reinforcements. For mixing of materials it is important to design a particular stir, specific parameters of stirring.

In 2015, Paul and Sijo [6] worked with an iron blades welded in iron rod. Due to high temperature welded zone will become less strong than earlier. They didn't describe thermal conductivity of his stirrer.

In 2103, Sharma et al. [7] author a normal layout of the complete setup. But he didn't describe his stirrer design with proper shape and analysis.

In 2006, Prabu et al. [8] described his work on stirring only with speed of rotation and time duration of stirring. Author didn't explain design and analysis of stirrer.

In 2011, Sajjadi et al. [9] author described layout of complete working setup and material of stirrer (Stainless Steel). They didn't show his proper stirrer design.
In 2013, Saravanakumr et al. [10] completed his experiments with different-different speeds of rotation and different-different time durations. But they didn't exact stirrer design and working condition with thermal conductivity.

\section{Research objectives}

The main objectives of the study are:

1. The main objective of this project work is to get fully distributed composite material.

2. To design temperature controlled electric furnace.

3. To design speed or rpm controlled stir for mixing of different- different molten metals.

4. To design insulated furnace and prevent explosion due to heat.

5. To design vibrations and shock free setup.

6. To fabricate complete stir casting machine setup in cheapest way.

\section{Importance of work}

Stir casting process is mainly used to produce automotive and aerodynamic parts. By using aluminium as base material with other reinforcements need best quality of the product for automotive and airplane parts. These composites are required to full fill all the required properties like strength, hardness, ultimate tensile strength, yield strength etc. of the parts.

From design point of view stir design is important because to get best properties of composite material it is necessary to distribute molten metal uniformly. To perform uniform distribution of molten metals, impeller is made up of graphite with helical gear cutting.

To eliminate use of nut and bolt to fix stir rod and graphite impeller internal threads will be used by creating hole on the middle of the graphite impeller.

To make furnace we used fire bricks of HA70 grade which can with stand at about $2000^{\circ} \mathrm{C}$ temperature which prevent an explosion to protect workers during working process. This chapter includes experimental setup, methodology and ANSYS aided during the current research.

\section{Designing and fabrication of stir casting machine}

Layout for the overall stir casting machine setup is made and is illustrated as show in Figure 1 


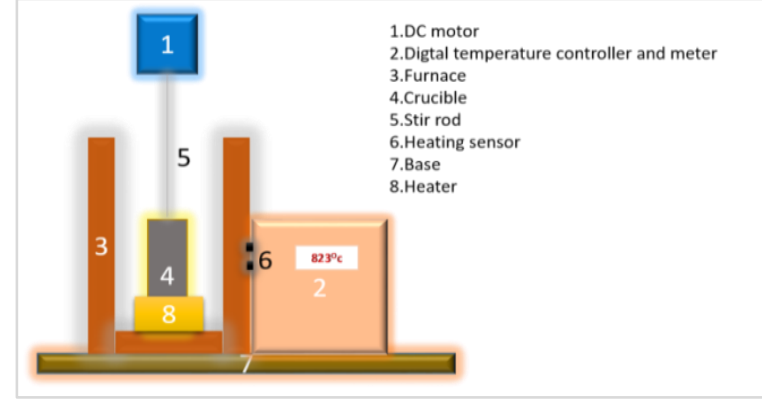

Figure 1 Overall machine setup

The complete setup is divided into two parts.

1. Furnace

2. Motor

In Figure 2 shows the arrangement of firebricks to fabricate furnace. This fire bricks used to prevent explosion due to working on high temperature.

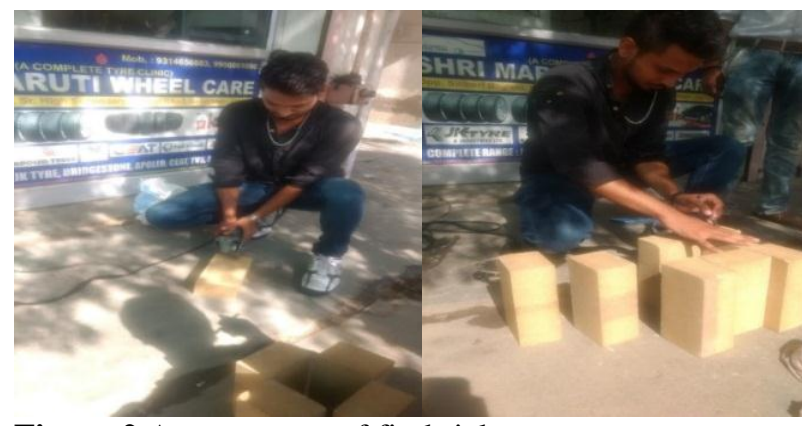

Figure 2 Arrangement of firebrick

\subsection{Experimental setup}

The Figure 3 shows the final experimental setup of stir casting machine that is designed to produce uniform distribution of particles in composite materials.
To fabricate stir and casting machine all the design models prepared by CREO 2.0. Figure 7, Figure 8, Figure 9 are showing the design model of helical shape stir, motor setup, and complete casting setup with stir respectively.

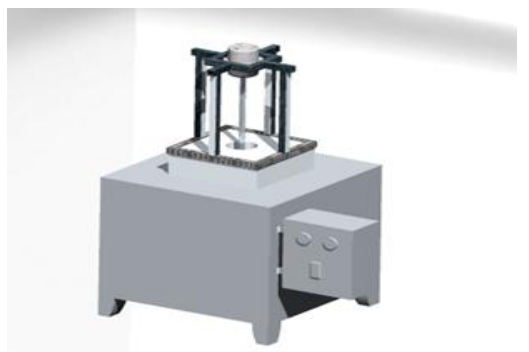

Figure 3 Final experimental setup of stir casting machine designed in CREO

\section{Results}

Experiments were carried out using helical shaped stirrer that was machined for studying the current research. It was observed that the helical shaped stirrer was in good condition even at $500 \mathrm{rpm}$. This finally proves that working with helical stir at 500 rpm gives uniform distribution for metal matrix composites.[3] According to the chemical composition test of sample made by mixing of $5 \%$ of reinforcement $(\mathrm{SiC})$ with aluminium in stir casting process, it results Silicon content in sample is $2.422 \%$ and aluminium is 95.18.[4].

\subsection{Drawings and simulation result}

Figure 4 shows the temperature and total heat flux analysis of crucible. Figure 5 shows the temperature and total heat flux analysis of graphite stir and steel rod. Figure 6 shows the design of helical type stirrer. Table 1 shows the ANSYS results on crucible.

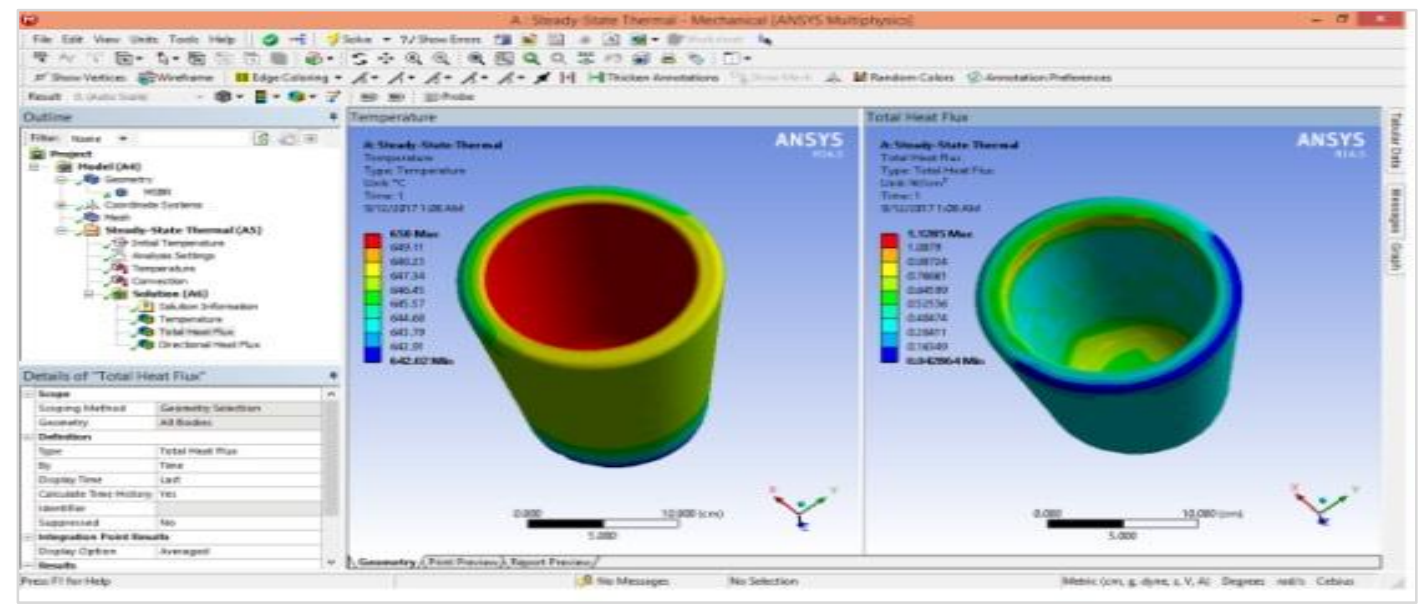

Figure 4 Temperature and total heat flux analysis of crucible 
Prajapati and Kumar

Table1 ANSYS results on crucible

\begin{tabular}{|c|c|c|c|}
\hline $\begin{array}{l}\text { Model (A4) } \\
\text { (A6) > Resul }\end{array}$ & Steady-State & herma & 5) $>$ Solution \\
\hline Object Name & Temperature & $\begin{array}{l}\text { Total } \\
\text { Hear } \\
\text { Flux }\end{array}$ & $\begin{array}{l}\text { Directional } \\
\text { Hear Flux }\end{array}$ \\
\hline State & Solved & & \\
\hline Scope & & & \\
\hline $\begin{array}{l}\text { Scoping } \\
\text { Method }\end{array}$ & Geometry Sele & ion & \\
\hline Geometry & All bodies & & \\
\hline Definition & & & \\
\hline Type & Temperature & $\begin{array}{l}\text { Total } \\
\text { Heat } \\
\text { Flux }\end{array}$ & $\begin{array}{l}\text { Directional } \\
\text { Heat Flux }\end{array}$ \\
\hline By & Time & & \\
\hline Display & Last & & \\
\hline $\begin{array}{l}\text { Calculate } \\
\text { Time } \\
\text { History }\end{array}$ & Yes & & \\
\hline Identifier & & & \\
\hline Suppressed & No & & \\
\hline
\end{tabular}

\begin{tabular}{|c|c|c|c|}
\hline \multicolumn{4}{|c|}{$\begin{array}{l}\text { Model (A4) > Steady-State Thermal (A5) > Solution } \\
\text { (A6) }>\text { Results }\end{array}$} \\
\hline Orientation & & & X-Axis \\
\hline $\begin{array}{l}\text { Coordinate } \\
\text { System }\end{array}$ & & & $\begin{array}{l}\text { Global } \\
\text { Coordinate } \\
\text { System }\end{array}$ \\
\hline \multicolumn{4}{|l|}{ Results } \\
\hline Minimum & $\begin{array}{l}643.34 \\
\text { Degree } \\
\text { Celsius }\end{array}$ & $\begin{array}{l}0.14303 \\
\mathrm{~W} / \mathrm{cm}^{2}\end{array}$ & $\begin{array}{l}-0.7802 \\
\mathrm{~W} / \mathrm{cm}^{2}\end{array}$ \\
\hline Maximum & $\begin{array}{l}650 \text { Degree } \\
\text { Celsius }\end{array}$ & $\begin{array}{l}2.1504 \\
\mathrm{~W} / \mathrm{cm}^{2}\end{array}$ & $\begin{array}{l}0.7802 \\
\mathrm{~W} / \mathrm{cm}^{2}\end{array}$ \\
\hline \multicolumn{4}{|l|}{ Information } \\
\hline Time & \multicolumn{3}{|l|}{$1 \mathrm{~s}$} \\
\hline Load Step & \multicolumn{3}{|l|}{1} \\
\hline Substep & \multicolumn{3}{|l|}{1} \\
\hline Iteration & \multicolumn{3}{|l|}{1} \\
\hline \multicolumn{4}{|c|}{ Integration Point Results } \\
\hline $\begin{array}{l}\text { Display } \\
\text { option }\end{array}$ & \multicolumn{3}{|l|}{ Averaged } \\
\hline
\end{tabular}

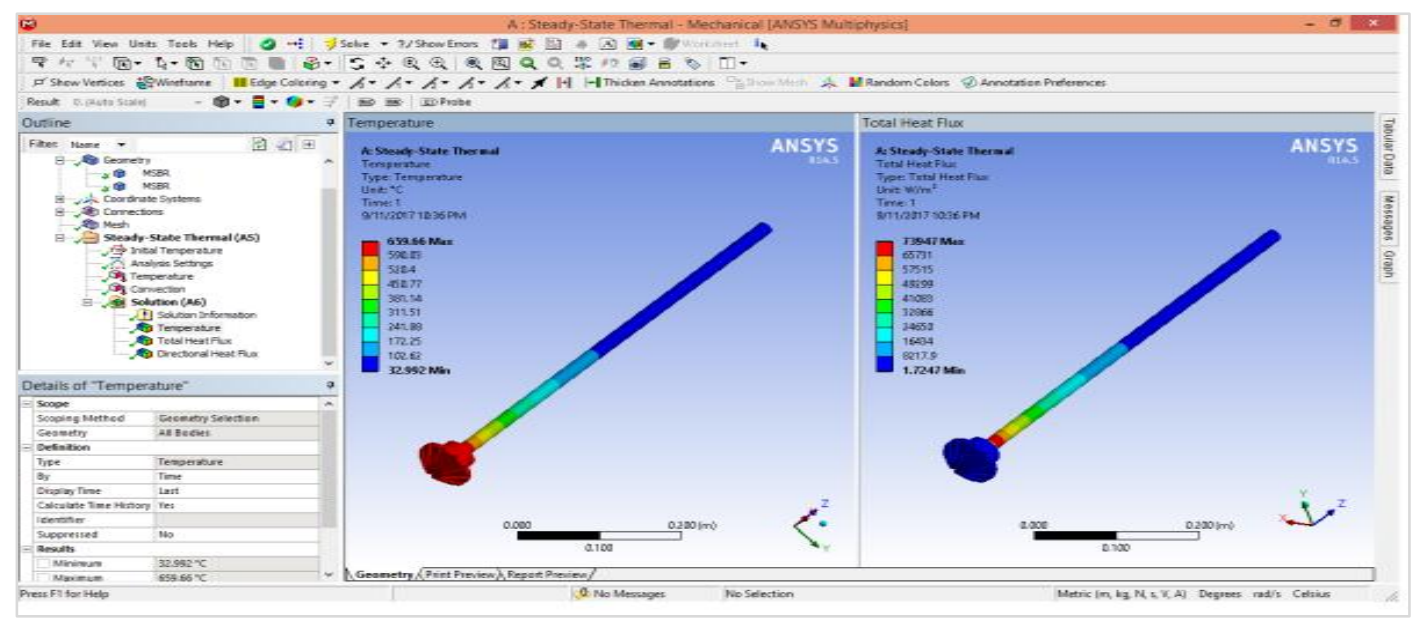

Figure 5 Temperature and total heat flux analysis of graphite stir and steel rod

We also discussed temperature and total heat flux of crucible and stir respectively. Table 2 shows the ANSYS results on stir.

Table 2 ANSYS results on stir

\begin{tabular}{|c|c|c|c|}
\hline \multicolumn{4}{|c|}{$\begin{array}{l}\text { Model }(\text { A4) }>\text { Steady-State Thermal }(\text { A5) }>\text { Solution } \\
(\text { A6) }>\text { Results }\end{array}$} \\
\hline Object Name & Temperature & $\begin{array}{l}\text { Total } \\
\text { Heat } \\
\text { Flux }\end{array}$ & $\begin{array}{l}\text { Direction } \\
\text { Heat Flux }\end{array}$ \\
\hline State & \multicolumn{3}{|l|}{ Solved } \\
\hline \multicolumn{4}{|l|}{ Scope } \\
\hline Scoping & \multicolumn{3}{|c|}{ Geometry Selection } \\
\hline Geometry & \multicolumn{3}{|c|}{ All Bodies } \\
\hline \multicolumn{4}{|l|}{ Definition } \\
\hline Type & Temperature & Total & Direction \\
\hline
\end{tabular}

\begin{tabular}{|c|c|c|c|}
\hline $\begin{array}{l}\text { Model (A4) > } \\
(\text { A6) }>\text { Result }\end{array}$ & Steady-Sta & ermal & $>$ Soluti \\
\hline & & $\begin{array}{l}\text { Heat } \\
\text { Flux }\end{array}$ & Heat Flux \\
\hline By & Time & & \\
\hline Display Time & Last & & \\
\hline $\begin{array}{l}\text { Calculate } \\
\text { Time History }\end{array}$ & Yes & & \\
\hline Identifier & & & \\
\hline Suppressed & No & & \\
\hline Orientation & X-Axis & & \\
\hline $\begin{array}{l}\text { Coordinate } \\
\text { System }\end{array}$ & Global Co & ate Syst & \\
\hline Results & & & \\
\hline Minimum & $\begin{array}{l}32.992 \\
\text { Degree C }\end{array}$ & $\begin{array}{l}1.7247 \\
\mathrm{~W} / \mathrm{m}^{2}\end{array}$ & $\begin{array}{l}-35525 \\
\mathrm{~W} / \mathrm{m}-2\end{array}$ \\
\hline
\end{tabular}


International Journal of Advanced Technology and Engineering Exploration, Vol 5(47)

\begin{tabular}{|c|c|c|c|}
\hline \multicolumn{4}{|c|}{$\begin{array}{l}\text { Model (A4) > Steady-State Thermal (A5) > Solution } \\
(\text { A6) }>\text { Results }\end{array}$} \\
\hline Maximum & $\begin{array}{l}659.66 \\
\text { Degree C }\end{array}$ & $\begin{array}{l}73947 \\
\mathrm{~W} / \mathrm{m}^{2} \\
\end{array}$ & $\begin{array}{l}33054 \\
\mathrm{~W} / \mathrm{m}^{2} \\
\end{array}$ \\
\hline $\begin{array}{l}\text { Minimum } \\
\text { Occurs On }\end{array}$ & \multicolumn{3}{|l|}{ MSBR } \\
\hline $\begin{array}{l}\text { Maximum } \\
\text { Occurs On }\end{array}$ & \multicolumn{3}{|l|}{ MSBR } \\
\hline \multicolumn{4}{|c|}{ Information } \\
\hline Time & \multicolumn{3}{|l|}{$1 \mathrm{~s}$} \\
\hline
\end{tabular}

\begin{tabular}{|l|l|}
\hline $\begin{array}{l}\text { Model (A4) > Steady-State Thermal (A5) > Solution } \\
(\text { A6) }>\text { Results }\end{array}$ \\
\hline Load Step & 1 \\
\hline Sub step & 1 \\
\hline $\begin{array}{l}\text { Iteration } \\
\text { number }\end{array}$ & 1 \\
\hline Integration Point Results \\
\hline $\begin{array}{l}\text { Display } \\
\text { Option }\end{array}$ & Averaged \\
\hline
\end{tabular}

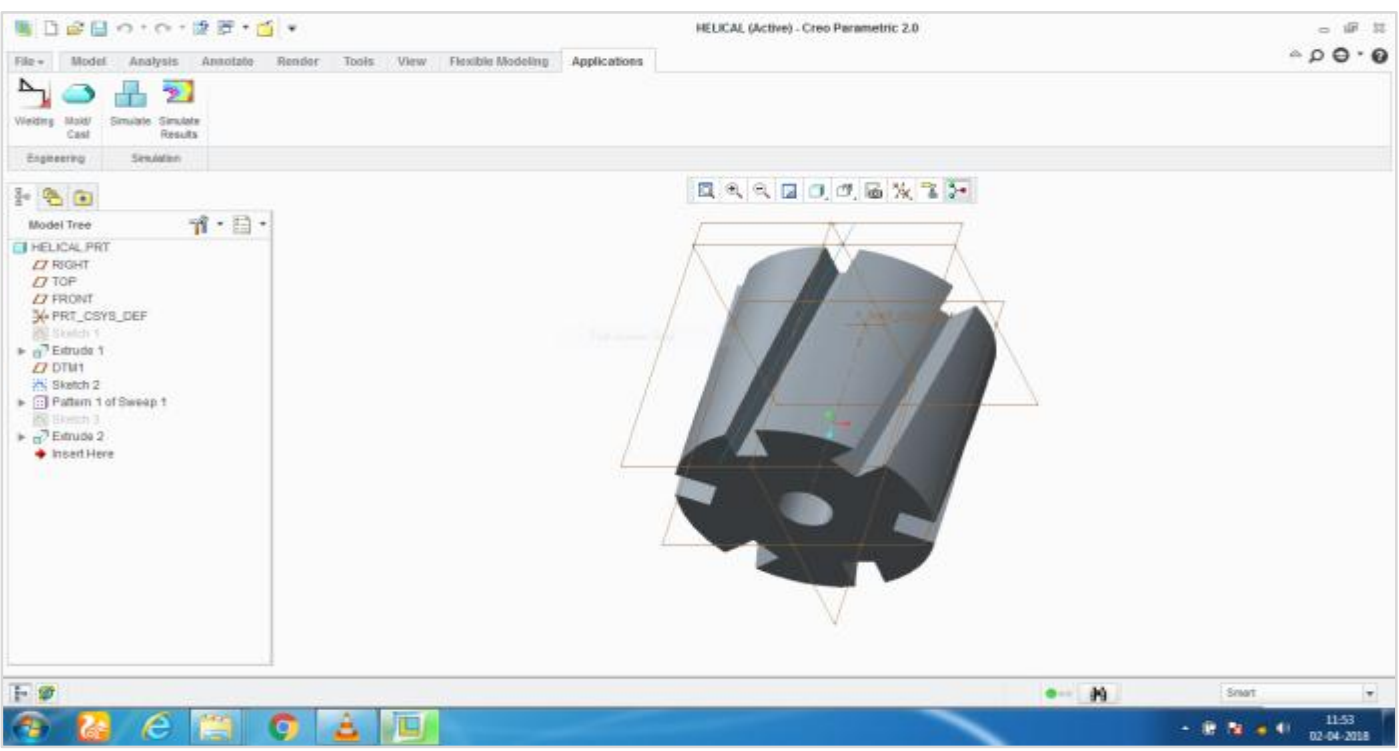

Figure 6 Design of helical type stirrer

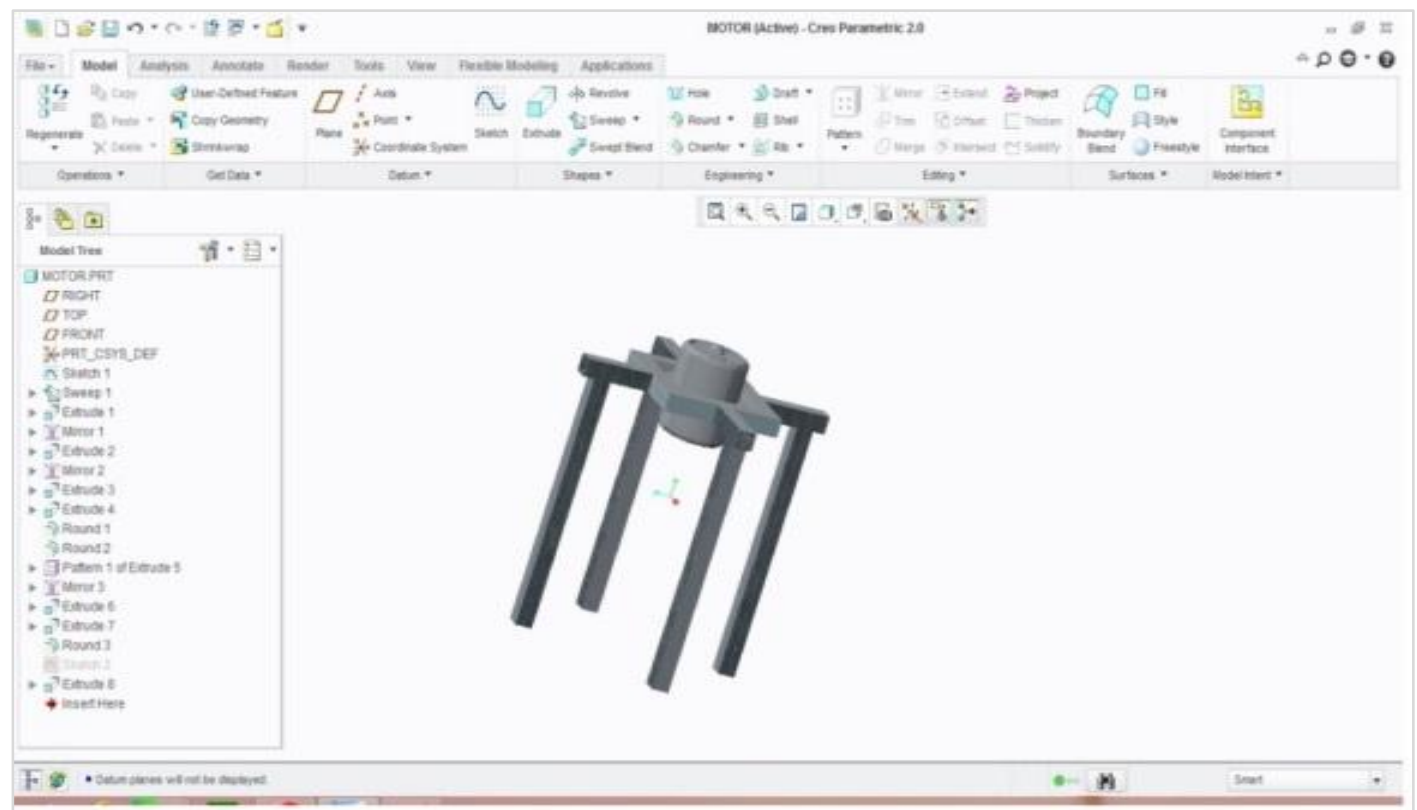

Figure 7 Design of motor setup 


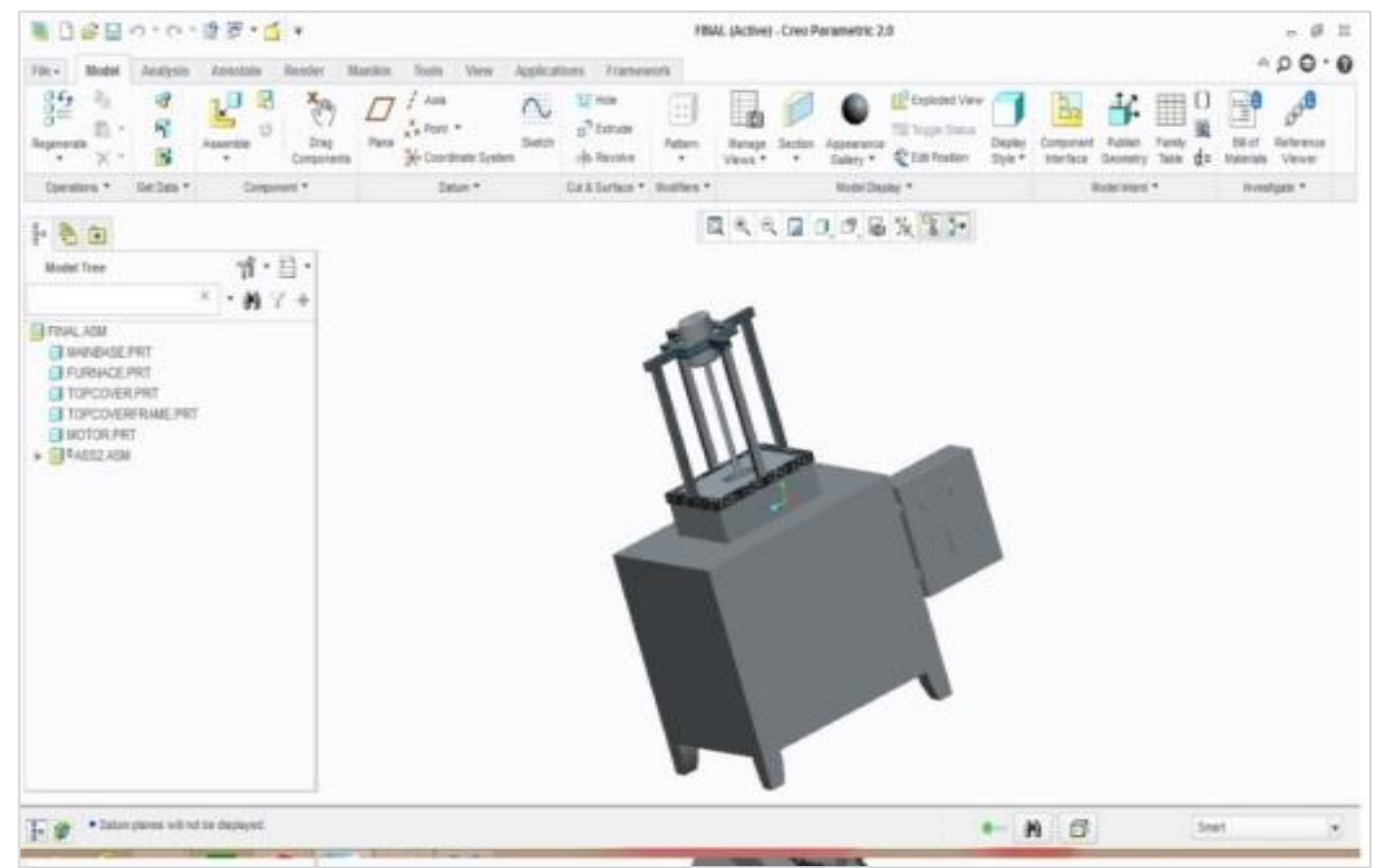

Figure 8 Design of final setup

\section{Discussion}

The research essentially aims at the stir design to improve uniform distribution of composite materials in stir casting process. The main objective of the project us to get fully distributed composite material. This objective is achieved by designing a temperature controlled electric furnace and also by designing speed or rpm controlled stir for mixing of different different molten metals. Stir casting process is mainly used to produce automotive and aerodynamic parts. By using aluminium as base material with other reinforcements need best quality of the product for automotive and airplane parts. These composites are required to full fill all the required properties like strength, hardness, ultimate tensile strength, yield strength etc. of the parts.

From design point of view stir design is important because to get best properties of composite material it is necessary to distribute molten metal uniformly. To perform uniform distribution of molten metals, impeller is made of graphite with helical gear cutting. To eliminate use of nut and bolt to fix stir rod and graphite impeller internal threads will be used by creating hole on the middle of the graphite impeller. To make furnace we used fire bricks of HA70 grade which can with stand at about $2000^{\circ}$ centigrade temperature which prevent an explosion to protect workers during working process. To remove any jitters occurring during the process of fabrication a 424 vibration and shock free setup is also designed. Finally, the stir casting machine setup is fabricated in cheapest way. The experiment was carried out for helical shaped stir and it was found that helical shaped stir has better performance at higher rpm. In order to learn about the furnace and vibrations ANSYS is used to analyses the crucible and the stir that is made used for the fabrication.

\section{Conclusion and future scope}

After studying previous papers on stir casting process we observed that authors didn't discussed in details about the design of stir. So, we designed stir to improve the distribution, and also discussed its temperature and study state thermal analysis to show its working capacity and its failure point. To prove our design we tested our stir by mixing and casting a composite material. We just added $5 \%$ weight of reinforcement in base material.

In the current research the material used for helical stir is graphite future work can be done by using other appropriate material and shape of the stir in order to produce uniform distributed composite materials. Current research uses HA70 firebricks for furnace, even this can be changed and studies for efficiency of the stir casting setup for various kinds of firebricks. Some more analysis can be done that leads to the improvement of efficiency and effectiveness of the fabrication process. 


\section{Acknowledgment}

None.

\section{Conflicts of interest}

The authors have no conflicts of interest to declare.

\section{References}

[1] Saravanan C, Subramanian K, Krishnan VA, Narayanan RS. Effect of particulate reinforced aluminium metal matrix composite-a review. Mechanics and Mechanical Engineering. 2015; 19(1):23-30.

[2] Kumar B, Parmar A, Ghoghalia D, Yadav M, Bhaduwala S. Wear analysis of aluminium based composites by stir casting process: a literature review. International Journal of Innovative Research in Science,Engineering and Technology.2015; 4(8):7253-9.

[3] Almadhoni K, Khan S. Review of effective parameters of stir casting process on metallurgical properties of ceramics particulate Al composites. IOSR Journal of Mechanical and Civil Engineering. 2015; 12(6):22-40.

[4] Sadi, Malau V, Wildan MW, Suyitno. Optimization of stir casting process parameters to minimize the specific wear of Al-SiC composites by Taguchi method. International Journal of Engineering and Technology. 2015; 7(1):17-26.

[5] Mansoor M, Shahid M. On the designing, efficiency, and stirring force of an induction coil for the processing of prototype $\mathrm{Al}$ based nanocomposites. Journal of Metallurgy. 2014.

[6] Paul KK, Sijo M. Effect of stirrer parameter of stir casting on mechanical properties of aluminium silicon carbide composite. International Journal of Modern Engineering Research. 2015; 5(8):43-9.

[7] Sharma P, Chauhan G, Sharma N. Production of AMC by stir casting-an overview. International Journal of Contemporary Practices. 2011; 2(1):23-46.
[8] Prabu SB, Karunamoorthy L, Kathiresan S, Mohan B. Influence of stirring speed and stirring time on distribution of particles in cast metal matrix composite. Journal of Materials Processing Technology. 2006; 171(2):268-73.

[9] Sajjadi SA, Ezatpour HR, Beygi H. Microstructure and mechanical properties of $\mathrm{Al}-\mathrm{Al} 2 \mathrm{O} 3$ micro and nano composites fabricated by stir casting. Materials Science and Engineering: A. 2011; 528(29-30):876571.

[10] Saravanakumr K, Venkatesh S, Harikumar P, Kannan K, Jayapal V. Studies on aluminium-graphite by stir casting technique. International Journal of Scientific and Engineering Research. 2013; 4(9):390-5.

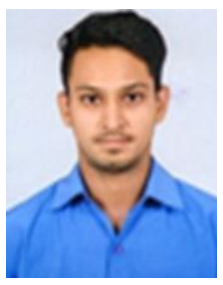

Sahil Kumar Prajapati is pursuing Master's degree in Manufacturing and Industrial Engineering from Suresh Gyan Vihar University Jaipur. His area of interst are Production planning and control, Quality control.

Email: sahilprajapatimech@hotmail.com

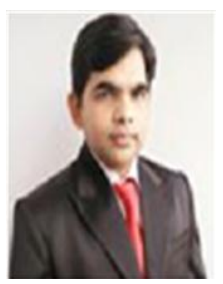

Dr. Neeraj Kumar holds Ph.D (Mechanical), M.Tech (Manufacturing System Engineering) \& B.E (Mechanical) with 11 years' of experience inclusive of 10 year as Engineering Teaching Faculty. Published four Books and 50 research papers. Presently Associate with Suresh Gyan Vihar University, Jaipur as a Professor \& Head of Mechanical Department. 